\title{
"Spiritualist Epistemology" between Science and Religion: The Transformation of Classical Science at the End of the 19th Century
}

Translation by Kathleen Hiatt

DOI: 10.22394/2311-3448-2016-3-2-53-78

Vladislav Razdyakonov - Center for the Study of Religion, Russian State University for the Humanities (Moscow, Russia). razdyakonov.vladislav@gmail.com

Experimental spiritualism as a fringe science played a significant role in Europe's intellectual life in the late 19th century. Its adherents considered questions of science and religion crucial for developing the right methods of scientific research. This article consists of four parts: (1) theoretical, which provides an overview of subject-object relations in the current theory of classical/non-classical epistemology; (2) historical, which investigates the opposition of "science" and "religion" as different spheres of modern human experience, and proposes a "reality principle" as the main principle of both classical epistemology and theology; (3) typological, which presents a typology of different epistemological models in Russian spiritualism based on the archival materials of its main adherents; (4) analytical, which deals with experimental spiritualism as fringe science that emerged during a paradigm shift from classical to non-classical science.

Keywords: spiritualism, spiritism, science and religion, history of science, A. N. Aksakov, N. P. Wagner, A. M. Butlerov, classical science, non-classical science.

"The living are always, by necessity of the case - and the more so the more we advance in time - under the government of the dead.

Such is the fundamental law of human order." (Comte 1858, 77) ow of Alexander Mikhailovich Butlerov, the late scholar of the Russian Academy of Sciences (RAN), received a letter from 
Nikolai Petrovich Wagner, an old friend of her husband's and future corresponding member of the Russian Academy of Sciences. Nikolai Wagner sought permission to publish the letters Alexander Butlerov had sent to him..$^{1}$ It would have been a trivial request if not for one serious contention. According to Nikolai Wagner, Alexander Butlerov wrote these letters after his own death:

The longer I live, the closer comes the hour of transitioning to the other world, the clearer and more threateningly the voice inside me speaks. It accuses me of making an unforgiveable mistake, having given you my word to not publish my spiritualistic research concerning the appearance of dear Alexander Mikhailovich in our séances. My testimony to it would have served a tremendous, decisive role and would have turned many unbelievers back to the path of truth, of this I am convinced. (Institut russkoi literatury (hereafter IRLI), fond 2, opis' 17, delo 21, listy 1-2) ${ }^{2}$

In fact, Wagner had already asked Nadezhda Butlerova in 1893, when she was living in the home of her relative, Alexander Nikolaevich Aksakov, for the chance to publish the materials and photographs he had received during séances. Even then she had declined, stating her wish to avoid having her husband's name once more "wrung" through the press, which would find an occasion to write extremely unflattering things about the deceased. Among other things, the photographs that Wagner had sent her did not resemble her husband in the least, since "you believe it your way, and I believe it mine. For this summer at a séance in Butlerovka he repeatedly told us, 'leave me in peace.' I consider it my sacred duty to do everything in my power to respect his wishes" (IRLI, f. 2, op. 17, d. 21, l. 2-2ob.). The conflict of interest was apparent.

Butlerov's spirit advised Alexander Aksakov, who did not feel well at the time, not to delay considering a successor (IRLI, f. 2, op. 5, d. 8, 1. 3). Furthermore, the spirit informed Aksakov through Wagner and Pribytkov's sister Varvara Ivanovna that he had taken on an unseen leadership role of the journal Rebus, recommending to Aksakov that he change its administrative policy:

1. Copied messages, rewritten seemingly by Wagner, entitled "Soobshcheniia s togo sveta" (Messages from that world), held at the Památník národního písmenictví (Memorial of National Literature) archive in Prague.

2. All citations to the A.N. Aksakov Fond in IRLI are according to a provisional electronic inventory (opis') of materials in the fond established by the author in 2012-14. Through a system of marked, identified documents, these folios (opisi) correspond to the number of the box of archival materials utilized by the author. 
I understand a thousand times over that with Pribytkov it will not break from the planned course, but I have different views for the journal, and I hope that in the near future new forces will emerge, which are necessary for giving the journal some life and activity. I would also like to set aside space in the journal for messages from the other side, where it would be possible to include advice and guidance on occasion. Now it is still early to do that, since Rebus is not ready for that and the transition to messages would be a leap forward in its life. . . . It is necessary to take the initiative and turn Rebus into a journal of psychological research in order to attract the power of the scholarly world. I repeat, with Pribytkov as editor this step is impossible, but soon I hope to bring in a person more capable of leading the journal as an organ of mediumism. (IRLI, f. 2 , op. 5, d. 11, ll. 19-19ob.)

Since these messages were of critical importance for Wagner, he was not satisfied with the widow's refusal and instead sought to obtain the support of the deceased academic's son, Mikhail Aleksandrovich. In his letter to Mikhail Butlerov, Wagner compared his group to a three-leaved clover, since, as he saw it, they were united in their pursuit of a common goal: fighting against a materialistic worldview and defending the reality of the spiritual world. However, as Nikolai Wagner writes, after the death of Alexander Butlerov and the cooling of his relationship with Alexander Aksakov everything changed: "The three of us with Alexander Mikhailovich [Butlerov] formed an unbreakable three-leaved clover: A. B. W. (Aksakov, Butlerov, Wagner $R V S)$. At the very least, that is what I thought and mistakenly so. The three-leaved clover has been torn apart! Alexander Nikolaevich and I were united by a noble and kind intermediary. This intermediary was your father" (IRLI, f. 2, op. 17, d. 21, 1. 1-10b.). However, despite this impassioned appeal, Mikhail Butlerov preferred to side with his mother, although he expressed interest in the manuscripts themselves and requested Wagner send them to him (IRLI, f. 2, op. 17, d. 21, 1. 10b.).

Alexander Butlerov's death sent shock waves not only through Wagner and those close to him, but also through the entire spiritualistic community. Spiritualists from all across the Russian Empire strove to summon his spirit in order to have the famous scientist confirm the reality of the spiritual world. Maria Petrovna Saburova, one of the most famous members of this movement in Saint Petersburg, reported that at her séances Butlerov gave advice about how she could handle Alexander Aksakov, who was seriously shaken by Butlerov's death, so that 
he did not lose faith in the key idea of the movement, the "proof of the existence of the soul" (IRLI, f. 2, op. 6, d. 1).

This article analyzes "experimental spiritualism" as a fringe program of scientific research. The primary subject is spiritualistic epistemology, first and foremost spiritualists' understanding of how to properly organize scientific knowledge. Focusing on the theory of $\mathrm{V}$. S. Stepin, which uncovers the historical dynamic of the development of scientific knowledge, this article seeks to reveal several characteristics of spiritualist epistemology that demonstrate its proximity to a non-classical conception of scientific cognition. The hypothesis of this article proposes that "experimental spiritualism" be seen as a fringe scientific program, which emerged during the transition from classical to non-classical science. A characteristic feature of this program is the eclectic blending of classical and non-classical ideas about the construction of scientific knowledge that partially contributed to its defeat in its struggle to obtain legitimacy in the eyes of the wider scientific community of that time.

This article consists of four parts: a theoretical portion reveals the content of classical and non-classical types of scientific knowledge through the prism of subject-object relations. A historical portion identifies the peculiarities in opposing "science" and "religion" as two different spheres of human experience in the modern age, while also confirming the "reality principle" of the object of cognition as a common characteristic of theology and classical epistemology. A phenomenological portion suggests a typology of the spiritualism movement in the Russian Empire, noting the specific variety of epistemological models of experimental spiritualism. This section also demonstrates spiritualists' attitude toward scientific knowledge, particularly of those spiritualists who were in no way connected with the scientific community. Lastly, an analytical portion discusses experimental spiritualism as a fringe science that arose during the transition from classical to non-classical science.

Spiritualist ideology, which is often characterized as "synthetic," aimed to go beyond the oppositions of "nature" vs. "culture" (the sciences and humanities) and "natural vs. transcendental" (science and theology) typical of late nineteenth-century philosophical discourse. The spiritualists were trying to confirm the exclusively "natural" character of communication of believers and the objects of their faith. Not all spiritualists, however, equated the "natural" with the "scientific." The space of the "natural" became a meeting point for "science" and "religion" as different ways of knowing. In order to 
grasp the form that this took, it is necessary to turn to modern philosophy of science and the historical relationship between science and religion.

\section{Subject-Object Relations in Classical and Non-Classical Epistemological Models}

Subject-object relations offer one of the most important methodological concepts for describing the process of scientific cognition. Historically this interpretation of scientific cognition specifically becomes dominant in Western European philosophical analysis of science in the modern era. Thus, on the one hand, "subject-object relations" as a distinct category provide a research tool for modern epistemology, and on the other hand, it is a necessary form of modern epistemology, without which it is impossible to discuss the epistemological foundations of Western European science. ${ }^{3}$

Western European philosophy's assertion of a particular vision of subject-object relations can serve as a marker, distinguishing modernity as a special period of development for Western culture. The beginning of the modern age is marked by the assertion of subject-object relations within the framework of the "classical model" of science, while its end is marked by the formation of a meaningful alternative to that vision within the framework of the "non-classical model" in the first half of the twentieth century. ${ }^{4}$ Thus, the modern, when seen through the prism of epistemology, ends when the "nonclassical model" occupies a dominant position in Western European philosophical discussions of the nature of scientific knowledge.

3. "Several authors propose replacing the theory of cognition with a broader understanding of 'philosophical knowledge.' There is also the argument that all of the older categories of traditional epistemology: subject, object, reality, objective knowledge, rationality, truth - have lost their meaning today. Clearly, in such an interpretation epistemology itself loses the right to exist.” V.A. Lektorskii, "O klassicheskoi i neklassicheskoi epistemologii," in Na puti $k$ neklassicheskoi epistemologii [On classical and non-classical epistemology, in On the path to non-classical epistemology], ed. V. A. Lektorskii (Moscow: IFRAN, 2009), 7.

4. In Russian philosophy of science the concept of "non-classical" is understood in relation to its history and epistemology differently. According to V. S. Stepin, "non-classical science" covers the period of its development in the beginning of the twentieth century until the 1970s. According to V. A. Lektorskii, "non-classical epistemology" arose as an answer to the call from modern cognitive and evolutionary epistemology since the 1970s. Furthermore, despite their divergence in historical analysis, as demonstrated, both authors include the unconditional intersections in assessing the "non-classical" character of subject-object relations. 
The first attempts to conceptualize the right relation of subject and object knowledge in scholarly research are connected with the works of philosophers such as René Descartes, who proposed the algorithm of scientific discovery (Discourse on the Method), and Francis Bacon, who articulated the necessity of liberating the subject from any external influence (idola mentis) and recommended observation, induction and experimentation as guaranteed methods of obtaining, deducing and verifying claims about the nature of things ("reflection theory"). The "classical model" is typically justified through reference to the fundamental works of Galileo Galilei and Isaac Newton, as well as through the indication of the model's various types in the works of philosophers who discuss scientific knowledge. Of these philosophers, perhaps the greatest historical significance can be attributed to John Locke (study of primary and secondary qualities), Immanuel Kant (Kant's Copernican revolution), and Auguste Comte (the positive philosophy of science).

One of the most important qualities of the subject is its detachment from the object; in order to correctly understand the nature of something being studied, one must first look at it from a distance. Presumably, the subject can reach an "ideal" position in relation to the object through preliminary procedures of self-purification of all biases against the object of judgment. From an epistemological perspective, such an "ideal" position would be defined by the Western European philosophical tradition as impartiality. An essential immutability emerges as the key characteristic of the object, guaranteed by the constancy of time and space, which determines the object's foundational "primary" qualities. The nature of the research object is considered identical to itself and independent of the subject of cognition. In this way, reaching the "ideal" position of the subject and following all scientific procedures allows one to reveal the true nature of things. ${ }^{5}$

The qualities of received "knowledge" partially coincide with the "values" about which Robert Merton spoke, pointing to its "universal-

5. "The ideal dominated during the stage of classical science, according to which the explanation and description should include only the characteristics of the object. References to a value-oriented structure of knowledge, on the foundation of materials and operations of activity, according to classical norms, should not figure into the procedures of description and explanation. Deviation from these norms is received as a rejection of the ideal of objectivity of knowledge." V. S. Stepin, "Klassika, neklassika, postneklassika: kriterii razlicheniia," in Postneklassika: filosofiia, nauka, kul'tura [Classical, non-classical, postclassical: Discerning criteria, in Postclassical: Philosophy, science, culture] (St. Petersburg: Mir, 2009), 249-95. 


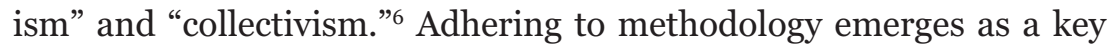
condition for the acquisition of knowledge, and of the different ways of receiving it perhaps the greatest weight is placed on comparison, which allows one to differentiate the essential qualities of a thing from its secondary qualities. In the classical model, justification of knowledge is most often carried out by pointing to its conformity to the nature of a thing ("the corresponding theory of truth"). The most important postulated characteristic of scientific knowledge is its integrity, since assessments about an object made within the framework of one scientific discipline cannot contradict the assessments made within the confines of a different discipline; in the case of a contradiction one of them inevitably must be considered false.

In the end, it is precisely the reference to the universal character of scientific "knowledge" that enables a number of eighteenth- and nineteenth-century philosophers to declare its principal epistemological superiority over other forms of knowledge. Typically these forms are not considered within the framework of the classical model as independent forms of knowledge, but rather as misconceptions. These misconceptions are either based on the incorrect conceptions of the subject ("theology") or do not possess the proper means of verifying the assessment, and have not escaped the impact of individual points of view concerning questions of ontology and "epistemology" ("philosophy").

The non-classical model is characterized by its serious revision of subject-object relations. Historically the formation of the non-classical model is typically associated with the crisis of rationality around the turn of the twentieth century, the formation of the phenomenological direction in Western European philosophy as an alternative to classical rationalism, as well as with a wide spectrum of scientific revolutions in natural science (Stepin 2009, 249-95). The non-classical model is normally grounded in its reference to the works of Niels Bohr, who confirmed the principle of complementarity in quantum theory, and Albert Einstein, who demonstrated that time and space were relative categories within the theory of relativity.

The key quality of the subject and object of investigation in the non-classical model is defined by their shared unity and variability. In the non-classical model the subject and object of study are interrelated, so that the same concept of subject-object relations be-

6. "The Merton ethos of science is the ideal model of scientific activity during the era of classical science.” Mirskaia 2005, 20. 
gins to be analyzed not as the relationship as such, but as a whole system, in which the subject and object appear connected to one another to the point that their separation seems to be a mere heuristic hypothesis, and not a rigid statement of fact. At the same time the system is regarded as being in a process of constant transformation, so any "knowledge" is relative to the concrete state of the subject and the object.

In contrast to the classical model, the subject is characteristically involved in the process of studying the object, which is manifested particularly clearly in the humanities. ${ }^{7}$ Phenomenology illustrates this thesis even more clearly by postulating the necessity of the research subject's involvement in the activities of the object: if you want to understand another person, you need to experience what he/she has gone through. ${ }^{8}$ Another, no less important quality is the dependency of the subject on the context in which it is located; science as an activity that produces "knowledge" is grounded in cultural and social factors governing the content of the subject's thoughts, including the content of any theories. ${ }^{9}$

The appeal to feelings within the phenomenological program highlights the pronounced irrational nature of this method of cognition, characterized as "empathy," "insight" and "integration [vzhivanie]." Isolation of the causes of the phenomenon, as a final result of the study, is declared futile and instead replaced with describing them, thanks to which it becomes possible to carry out comparisons and establish a classification of studied phenomena.

The resulting "knowledge" appears to always be relative to the experience of the interaction between subject and object and, correspondingly, cannot claim to be of an absolute nature. Indeed it seems that this "experience," taken as a whole, determines the contextual-

7. For more on contemporary efforts to create such a philosophy of cognition, see Mikeshina 2005, 33-38.

8. Phenomenology's interpretation of religion is demonstrative in this regard, in part confirming the necessity of religious experience in order to understand religion. "We call to remember a moment of strong and, as much as possible, one-sided religious fervor. Those who cannot do that or those who have never experienced such a moment, we ask read no further." R. Otto, Sviashchennoe: ob irrational'nom $v$ idee bozhestvennogo $i$ ego sootnoshenii s rational'nym [The sacred: On the irrational in the idea of the divine and its relationship with the rational] (St. Petersburg, 2007), 15.

9. “A 'constructivist' outlook . . regards scientific knowledge primarily as a human product, made with locally situated cultural and material resources, rather than as simply the revelation of a pre-given order of nature.” J. Golinski, Making Natural Knowledge: Constructivism and the History of Science, XVII. (Chicago: Chicago University Press, 2005). 
ity of knowledge. Accordingly, the justification of the value of such knowledge is often pursued either by social criteria (the "conventionalist" theory of truth), or by pragmatism (the idea of utility independent of truth). Furthermore, by pointing to the relativity of "knowledge," certain modern philosophies of science have concluded that various forms of knowledge, such as theological and scientific, at least on a purely theoretical level should be recognized as equal. From there it follows that neither of them can claim to have epistemological advantage or use politics as a means of promoting their own worldview (Feierabend 2007, 36).

\section{The Conflict of Science and Religion in the Modern Era and Belief in "Reality"}

From the perspective of history of science, the classical epistemological model was formed in the early modern period through its gradual juxtaposition to other forms of knowledge. That event, which in older historiography is standardly labeled the "Scientific Revolution," can be viewed as a watershed, lying between the "old" and "modern" eras. ${ }^{10}$ The Scientific Revolution is presented as a long process of forming new epistemological priorities, beginning in Western Europe in the seventeenth century and ending in the nineteenth century.

The Scientific Revolution ushered in the negation of the "old" scientific view of the world, tied to a Christian systematic theology (Barbour 2001, 3-37). The gradual weakening of its influence was accompanied by the Scientific Revolution, which emerged as a significant factor in European secularization and the gradual removal of Christian doctrine, along with that of other religions, from the public sphere. The end of the Scientific Revolution came at the beginning of the nineteenth century, and was marked by the emergence of the philosophy of early positivism, which proposed a unified theoretical conceptualiza-

10. The author consciously combines two types of rhetoric: "procedural" and "event-driven [sobytiinyi]." Conflicts between representatives of the old and new historiography reflect historians' different methodological approaches. One group is oriented on determining the differences between forms of knowledge, the other focuses on determining their similarities. One establishes the borders between epochs, the other on their correlations. In the juxtaposition of this somewhat futile dispute it is worth confirming the complementarity of various descriptions, and not dismiss the "classical," "presentist" view of history, despite the fact that it specifically provides the totality of history and invests it with mythological meaning, which ensures the unity of the scientific community through its recognition of the unity of its own history. 
tion of "science" as an independent sphere of human activity. ${ }^{11}$ It was precisely at this time that foundational concepts of European modernity began to receive a wider circulation. Concepts such as "science," "religion," "culture" and "society" appeared as tools for educated Europeans to comprehend the world around them. In this connection, it can be productive to analyze the broad nineteenth-century discussion of the conflicted nature of the relationship between "scientific knowledge" and "Christian theology" as a consequence of the assertion of a new epistemological paradigm.

Furthermore, the relationship between "religion" and "science" has only grown increasingly complex, forcing philosophers of the modern age to repeatedly compare the two, not through the contradictions of their individual content, but through finding their shared characteristics as holistic systems of knowledge. One of the foundations of Western European scientific tradition is the Pythagorean-Platonic universal idea, the discovery of which came through the help of rational mathematical proofs, and the experiment serves as a means for verifying the "universalism" of obtained data (dannye). ${ }^{12}$ That which does not yield to mathematical calculation is declared unknowable by scientific methods and lies beyond the reaches of scientific research. However, originally the idea of mathematical knowledge was directly connected with divine knowledge in that it was general and universal. ${ }^{13}$ This view of learning about nature as its own way of learning about God (or in the Christian tradition, mildly put, as a way to learn about the Divine Plan and its creation) was generally characteristic for the founders of European science. ${ }^{14}$

11. This approach overlaps, and simultaneously, polemicizes the position introduced in the works of Cunningham and Williams 1993, 407-32. For a broad overview of the history of interpretations regarding science and religion beginning with Comte, see Gregory $2003,329-58$.

12. "The real world is the world which is beholden exclusively to quantitative relationships. . . Mathematics is the language and the perfect model of the Universe." Svetlov 2008, 97.

13. In contemporary historiography, the issue over the relationship between "science" and "religion" in early Greek philosophy remains a discussion, taking into account the relational nature of its research concepts, as well as the prevalence of mythological material in early Greek historiography of science. For more on the example of Pythagoras' work and its interpretation, see Zhmud' 2012.

14. The basis of this thesis is dedicated to the majority of historical works on the problems of the mutual relationship between "science" and "religion" in the early modern era Several researches suggest that organization of scientific knowledge and its ethical code also correlate with "religious" examples. Saprykin 2000, 194-208 and Merton 2000. 
Thus despite the fact that in their content the classical model of scientific knowledge and theology derive from different ontologies (that which in fact exists) and epistemologies (how to recognize that which exists), the most important shared quality of the two is their affirmation of a belief in the existence of a true reality and the fundamental possibility for humankind to reach it. Precisely this belief can explain the typical desire in scientific thinking to move beyond the bounds of conceptual frameworks created by human thought, ${ }^{15}$ as well as opposing acquired "knowledge" to former "knowledge," announcing another Scientific Revolution and gradually moving closer toward understanding the essence of an object of study. ${ }^{16}$

However, as the conflict between "science" and "religion" acquires ideological and social dimensions, "science" begins to be analyzed as a form of knowledge, which reveals the laws of the natural world independent from any kind of connection to received knowledge of the idea of God. In turn, "religion" begins to be identified as a part of the given nature of mankind, with its sources (regardless of which religion is concerned) in the seventeenth through nineteenth centuries increasingly declaring that on one side there were human feelings and thoughts and on the other there was nature, which was open to interpretation and experience. ${ }^{17}$

The juxtaposition of "science" and "religion" in the modern age has three primary dimensions: epistemological (God and Nature as dis-

15. 'I believe in 'absolute' or 'objective' truth in the sense of Tarskii (although I, of course, who am not an absolutist in that sense, do not consider, that I or someone else has truth in their pocket) ... I allow, that in any arbitrarily chosen moment we are hostages to the conceptual framework of our theories, expectations, our previous experience, our language. But we are not hostages in the literal sense. If we so choose, we can escape from our framework at any time. ... The idea that different frameworks are similar in their mutually untranslatable languages is dogma, and a dangerous dogma at that." Popper 2003, 323. For more on the religious foundations of scientific thought, see Markova 1997, 219-64.

16. "Yet the great minds who laid down the foundations of modern mentality - John Locke for example - had reason for their dissatisfaction with the traditional dogmatic theology, though they partially misconceived the grounds on which they should base their attitude. Their true enemy was the doctrine of dogmatic finality; a doctrine which flourished and is flourishing with equal vigour throughout Theology, Science, and Metaphysics." Whitehead 1967, 162.

17. "I maintain that cosmic religiousness is the strongest and noblest motive for scientific research. . . . Only one who has devoted his life to similar ends can have a vivid realization of what has inspired these men and given them the strength to remain true to their purpose in spite of countless failures. It is cosmic religious feeling that gives a man such strength. A contemporary has said, not unjustly, that in this materialistic age of ours the serious scientific workers are the only profoundly religious people." Albert Einstein, The New York Times Magazine, November 9, 1930, pg. 4. 
tinct objects of cognition, different methods of obtaining knowledge); socio-political (the fight of social institutions and their participation in the struggle for power); and ideological (the contradictory descriptions of events and processes). The conflict between science and religion in the modern era is identified in various ways, however one of the most notable is that many scholars create an opposition between general statements of "universal" science and "private" views of religion. ${ }^{18}$ Furthermore, science claimed to discover a common "natural" basis for diversity of the world of human culture, and also positioned itself as the universal platform for dialogue between people.

It is worth mentioning that such opposition of "science" and "religion" in the modern era, it seems, is genetically linked to the JudeoChristian opposition of the Creator with the world he created (Gaidenko 2006, 79-119). One could even suggest that the idea of the "independence of science and religion" emerges in European philosophy in the modern era as a derivative of a Christian-Platonic interpretation of the divine as transcendental, "wholly other" (to use the terminology of R. Otto) in relation to the created world. However, the opposite could also be stated: the basis for this opposition of science and religion can be found in Parmenides" division of "truth" and "opinion," which contrast as "singular" and "plural," and is rooted, it seems, in the characteristics of human thought that have an innate ability to differentiate natural processes from those it deems supernatural. ${ }^{19}$

However, such a differentiation of science and religion as "universal" and "particular" spheres did not suit many philosophers and scientists, since, in their view, it suggested overcoming the contradiction between "universal" science and "particular" religious knowledge. Christian theologians faced a similar problem of combining "universal" and "particular" viewpoints even in the thirteenth century, when they attempted to cope with the challenge of Aristotle's philosophy,

18. The famous motto of the London Royal Society, Nullius in verba, best conveys the typical attitude toward the authorities' views, if it is not based on experimental evidence. The propaganda of such an attitude becomes a departure point in the works of a number of French Enlightenment scholars, and finds its final conceptual form in the first wave of positivist philosophy. See Osler 2013, 31-52.

19. In this regard it is worth noting B. Malinowski's argument that in everyday life a primitive person understands well where the border between natural and supernatural lies. Malinowski 1998, 19-91. Furthermore, the understanding of certain things, events and processes as supernatural can be explained as a lack of adequate knowledge on behalf of a primitive person. Attributing a "supernatural" quality to this or that object seems to be the only method of including it in everyday, "natural" life. 
and even then, "studies on the twofold mode of truth" led to a plethora of skeptical rebuttals from conservative-minded thinkers (Grant 1996, 70-85). It is not surprising that in addition to the large number of scholars and theologians who worked within the confines of "normal science" and privately proposed the idea of the separation of science and religion, the modern age bore witness to a great number of revolutionary attempts to overcome this contradiction.

These attempts manifested themselves in two ways, depending on which principle - the "universal" or the "particular" - the actor in question preferred. For example, many philosophers moved "from science to religion," typically adhering to the idea of Deism in their interpretation of the relationship between God and the world, and developed the concept of "natural religion." Religion "within the limits of reason" developed through the framework of various quasi-religious cults of the era of the French Revolution and the positive religion of Auguste Comte (Wright 2008). At the end of the nineteenth century the baton was taken up by new religious movements, such as theosophy, which asserted the equivalence of different paths to attaining the truth and spoke of a fundamental unity between all religions, despite their individual differences (Falikov 2007, 19-51). In such an approach, religion is interpreted as an innate human characteristic and is characterized first and foremost as an ability or a special kind of intimate relationship toward a sacred object. Religious teaching and cult become increasingly abstract and in many instances play either a secondary role, or in principle, are not seen as having any kind of significance (znachenie).

The opposite movement, "from religion to science," was introduced by philosophers and scientists, who strove to preserve and defend the specific teaching of their own religion. The "natural theology" movement became the most notable manifestation of this in the modern era, as it attempted to strengthen the idea of the Divine Creation and Plan with scientific arguments (Brook 2004, 166-93). Biblical creationism, which declares the need to verify the "universal" assertions of science through the private truths (chastnymi istinami) in the biblical text, is a typical contemporary representation of a similar relationship to science as an instrument for confirming religious doctrine.

Experimental spiritualism, as will be demonstrated below, cannot be attributed to any of the indicated discourses of European thought. Precisely that fact has compelled researchers to resign it to a "fringe" phenomenon that does not fit into the general picture (for example, attempts have been made to fit it either into the logic of secularization, 
or conversely, to demonstrate its "conservative" nature). It is possible to explain such ambiguity in spiritualism if one looks at it as one of the transitional forms that arose during the transition from a classical to a non-classical epistemological model.

\section{"Scientific" and "Religious" Types of Spiritualism in Russia in the Nineteenth Century}

Within the scope of this study, I define "spiritualism" in the broadest sense as the belief in the existence of spirits and the possibility of communicating with them. In the nineteenth century, that belief became the subject of a fierce polemic between members of different social groups: scientists and priests, publicists and independent researchers discussed whether spiritualism as a specific practice was capable of providing an answer to the question of the real existence of the human "spirit." All those who positively answered the question pointed to a direct "experience" of communicating with spirits as the primary evidence of their existence.

"Experience" is a notion that simultaneously stems from both the romantic and the positivist lexicon. The fundamental difference in its interpretation lies in the fact that for the romantic, "experience" is directly felt by the subject of cognition, while for a provisional positivist, "experience" must have universal significance and be totally independent of the subject. For both, "experience" provides access to reality, however, if the romantic discovers it in all the fullness of the subject's feelings, the positivist discovers it through thoughts and senses shared by everyone.

Spiritualism as a specific ideology and practice arose at the intersection of positivist and romantic discourses. Drawing on the common nineteenth-century juxtaposition between "science" and "religion" as public and private knowledge, Russian spiritualism as a cultural phenomenon can be divided into two ideal types: "religious" and "scientific." The religious type of spiritualism is the religion of direct experience of encountering the "sacred," the origins of which in Christianity must be sought in the Reformation movement and broadly, in Christian apophatic mysticism. For such religion the following is characteristic: condemnation of the passive absorption of tradition; although reflection about the object cannot replace meeting with it face to face, the mind is viewed as the single possible means of interpretation of religious experience; cult practice and doctrine are seen as secondary to religious experience; science as a means of knowing the world through 
the help of controlled or repeatable experiments is either directly rejected or demonstrated to be insufficient for knowing the world.

The scientific type of spiritualism is a variety of scientific practices unrecognized by the scientific community, which aims to study the world of spirits as part of the natural world. In its essence, it is a "scientific" kind of natural theology, dating back to Antiquity and aiming to use rational means to confirm the existence of various articles of faith. The scientific type of spiritualism strives on behalf of the spiritual world to expand the space of the "natural," which it views as the only real one, and often skeptically treats any form of "transcendental" as imagined. In the historiography of the issue it is often named as a side effect of scientific development, primarily defined as a specific direction in psychology, which set as its goal empirically demonstrating the independence of the human psyche from its material body.

From a historical-cultural point of view, the proposed typology has a heuristic benefit: in the internal polemic that occurs between representatives of the aforementioned types, the desire arises to overcome the dividing lines between the spheres of "science" and "religion." The content of the proposed typology is not static: in a historical perspective, the views of many thinkers undergo a transformation, shifting from one end of it to the other (for example, from the "objectivism" of science to "subjectivism" of religion). At the same time, it makes it possible, with reasonable accuracy, to demonstrate the specific diversity of spiritualism, uniting under its banners people who differ from one another in their view of the correct relationship of science and religion.

It is necessary to attribute to the "scientific" type the activity and work of the three major apologists for the scientific study of the phenomena, which took place at the so-called spiritualist séances: Alexander Nikolaevich Aksakov, Alexander Mikhailovich Butlerov, and Nikolai Petrovich Wagner. The formation of the Russian scientific community of researchers of mediumistic phenomena took place during the 1870s, when Alexander Butlerov first became acquainted with them, then Nikolai Wagner, and finally, it achieved its greatest degree of publicity thanks to the activity of a special commission, constituted at the Physics Society of St. Petersburg University (1875-76). The 1880 os and beginning of the 1890 os represented the peak of organizational and publication activity of the movement, however toward the turn of the century it began to lose its influence, largely unable to compete with the religious type of spiritualism (Razdyakonov 2010, 162-71). 
The specific methodological position of researchers of mediumism allows one to speak of three types of the "scientific" kind of spiritualism: "experienced" (Alexander Butlerov), "theoretical" (Alexander Aksakov) and "doctrinal" (Nikolai Wagner). These types of scientific spiritualism can be further delineated by the extent to which their conclusions, as obtained on the basis of the content analysis of individual experiments, take on a global character.

Alexander Butlerov rightfully held the authority of a distinguished scholar in Russia. For this reason, in his archive one can find a substantial number of letters from amateur spiritualists, asking that he place their pursuit of spiritualism "on a scientific basis." The typical argument in these letters fell along the lines of:

Believe, professor, that it is not mere curiosity that drives an idle person with equal force to a spiritual séance and the performance of a magician. It is not that feeling that compels me to appeal to you as the center and natural leader of those, who share a serious attitude toward spiritualism... You alone can give our circle direction. You alone can establish our séances on a rational basis ... since you alone unite in your person and your faith that kind of appearance and compelling authority of a serious (glubokii) scholar. (IRLI, f. 2, op. 17, d. 48, 1l. 1ob.-2ob.)

Consequently, in the "three-leaved clover" Alexander Mikhailovich Butlerov had the undisputed "scientific" authority. Aksakov did not have any kind of academic credentials, and Wagner soon gained the reputation of an eccentric.

Compared with his fellow spiritualist enthusiasts, Alexander Mikhailovich Butlerov occupied a cautious position in regard to mediumistic phenomena. He recognized the reality of "mediumistic facts" and on this point he was ready to agree with the statement of mathematician Auguste de Morgane: "The physical explanations which I have seen are easy, but miserably insufficient: the spiritual hypothesis is sufficient, but ponderously difficult" (Butlerov 1889, 66. Original quote: Morgan 1863, vi). In this way, he viewed the spiritual hypothesis as one possible explanation and deliberately left it as a hypothesis.

Characteristically, in the last years of his life Butlerov was less interested in spiritual phenomena. Aksakov writes to Wagner about this with some annoyance, advising him to update the contents of his posthumous article about Butlerov: "You say that Alexander Mikhailovich 'no longer' (?) took interest in phenomena. Here you must be careful, otherwise they will take it and misinterpret it. It is necessary to ex- 
plain: having become convinced of the essence of matter and having seen enough of it, A. M. took little interest in repetition, but greater interest in specific (indiscernible, possible "cases"- RVS) or in those conditions, that did not permit full control" (IRLI, f. 2, op. 2, d. 45, l. 1-10b.).

In the program of lectures that debated the question of the relationship of mediumistic research and Christianity, Butlerov writes that one does not contradict the other at all, as far as "scientific" knowledge and "religious" knowledge are independent of one another (Pribytkov 1901, 124). Mediumism does not cause any harm to Christianity, presenting itself as merely a new realm of positive knowledge about nature. Furthermore, this knowledge can ultimately be used by Christianity, since it can potentially confirm the existence of souls and refute materialists:

This issue represents a domain of pure positive knowledge, since its entire center (1.2) of gravity lies in facts, now considered to already be undeniable by a considerable number of authority figures. As a branch of factual knowledge, the issue of mediumism, similar to other branches of science, obviously cannot be subject to delay or removal by any kind of external means.... On the basis of these undeniable facts, more or less probable conclusions and deductions can be drawn, among which, the conclusion on the existence of the spiritual world and man's transfer into it upon the death of its body is of particular significance, a view in direct contradiction to materialism (1. 20b.). ... This view equally agrees well with the basis of the most diverse religious views, not at all linked exclusively with any one of them. All further conclusions from the reality of mediumistic phenomena will be completely arbitrary and can be made solely on the basis of superstition, that is, in those conditions under which false teaching and belief often find an imagined support in the basis of complete truth. Encountering materialism, mediumism easily prevails, countering it with real facts, that is to say the very same upon which materialism imagines itself resting. ${ }^{20}$

20. IRLI, f. 2, op. 10, d. 113, l. 2. A. M. Butlerov, Kopiia pis'ma Iu. Aleksandru Nikolaevichu (tsenzoru Rebusa). Rukoi N. M. Butlerovoi. 1886 19/IV [Alexander Butlerov. Copy of a letter to Iu. Alexander Nikolaevich (the censor of Rebus). Handwriting of N. M. Butlerova. April 19, 1886]. Count M. M. Petrovo-Solovovo (1868-1954), a representative of the "young" generation of researchers of mediumistic phenomena, held a similar position, having joined the English "Society for Psychical Research" in 1890, which adopted a generally critical position concerning the correct interpretation of phenomena with the help of the "spirit hypothesis." 
Aksakov and Wagner's attitudes toward "scientific" and "religious" knowledge have already been explored in other publications, therefore this article will be limited to general assertions about their attitude (Razdyakonov 2013, 55-72). Compared to Butlerov, Alexander Aksakov went further, not only recognizing the reality of mediumistic facts, but also specifically working to defend their "spiritual" interpretation. Aksakov's main work, "Animism and Spiritualism," was dedicated to the possibility of a scientific basis for the "spirit hypothesis," an explanation whose a priori rejection by the scientific community caused serious objections from his supporters.

Nikolai Wagner, in turn, not only recognized the "spiritual hypothesis," but also interpreted the content of messages received "from spirits" with the goal of illuminating their "doctrine." Significant differences between him and Alexander Aksakov in understanding how one should properly conduct research on mediumistic phenomena ultimately led to a schism among the leaders of the scientific type of spiritualism. The religious-philosophical theories Nikolai Wagner formulated toward the end of his life attest to his evolution from the "scientific" to "religious" type of spiritualism.

To characterize the divergence in views between Aksakov and Wagner, it is enough to quote Wagner's own words addressing Butlerov: "Aksakov looks at not only me, but also you and all scholars with dismissive condescension. For him, science is a materialistic hindrance in developing the appropriate view on things. Consequently, it is a stupidity not worth pursuing. Both you and he try to bend science toward spiritualism, but I wish to bring it under the principles of spiritualism. Inde ira (Lat. Hence wrath) and intractibility in our views (IRLI, f. 2, op. 17, d. 20. 1. 1ob.). If Aksakov spoke a great deal in his publications about "Orthodox dogmatics," which interfered with the progress of scientific knowledge, then for Wagner this question had already been decided by the end of the 1880 os. Specifically then he communicated with "the spirit" of Butlerov through the means of various mediums, and as a result in his book, Observations on Mediumship, he formulated his own religious-philosophical teachings, which he deduced from the messages of good spirits.

As for Russian "religious" spiritualism, it can be divided into types based on the specifics of religious doctrine. These types are often divided into two groups, French and Anglo-American spiritualism. However, at least in Russia, it is possible to establish a more complex picture, involving contention between various teachings within the spiritualist religious field (for example it is necessary to 
note the followers of the teachings of Swedenborg, and also the significant number of spiritualists who did not break with the Orthodox Church). Without going into the details of the features of the specific diversity of that type, one must bear in mind one of its key characteristics: although its proponents used pseudo-scientific terminology to describe their own spiritual experiences, they were extremely critical of science as a method of cognition, asserting the inadequacy of its methods for studying the realm of the spiritual world. An excellent example of this type of attitude is provided in the spiritualist diary of M. P. Saburova. (For the social and psychological aspects of the diary's contents, see Razdyakonov 2015, 55-69.) Although one regularly finds the use of scientific rhetoric in this diary, in the author's opinion, abstract science claiming objectivity in comprehending a subject will always leave room for a skeptical attitude toward mediumistic phenomena. ${ }^{21}$ Only the direct experience of communication between a deceased individual and his family offers the guarantee of "spiritualist conversion": "if faith also went along with science, then much would be discovered by your scientists" (Saburova, 3:58). Furthermore, criticizing the possibility of objectivity of the scientific method, M. P. Saburova did not doubt in the slightest the existence of the "natural" world of spirits she had discovered. "Miracles" and "spirits" continued to remain a part of it, however they could not be known through the scientific method, or rather they could not be objectified, for they belonged to the world of irreducible subjective "experience":

But why did he put a sign [an image of a wavy line - RVS] instead of the word "materiality"? Likely because they consist of matter: if he had said "it has not yet received materiality," then it would be possible to think that there is no matter in their world, when there is a shell (obolochka) and form there. And in their world spirit and matter appear in union, but how could we, with our limited eyes, which are arranged and suited for the narrow field of earthly activity, how can we behold unearthly things

21. "The invisible have the possibility to unite their currents [toki] and the currents of the medium ... like a telegraph wire, since these currents can be broken and reconnected at will. It is possible to understand this, but by what means the connection occurs is not within our understanding." M. P. Saburova, Gody moei zhizni . . . vol. 3, p. 7; "And your scholarly séances do not lead to anything. ... No one can understand us [postich'] with science: here only faith in future life is necessary - everything will be clear." Ibid., vol. 1, p. 43 . 
with them, which are ephemeral and so completely evade our senses! (Ibid., 1:146)

In this way, the spiritualist anti-scientific discourse argued that a special "spiritual" realm (oblast') of the natural world exists, which people are not able to understand, yet insofar as it is natural, it definitely exists. Access to it became possible only thanks to a direct "subjective" experience (perezhivaniia), and therefore they always recommended giving spiritualist practice a try at least once before passing a final judgment on the subject. Appealing to subjective experience, religious spiritualism came as a predecessor to later phenomenological conceptions, which aimed to overcome the classical understanding of subjectobject relations in scientific knowledge.

\section{Spiritualism and Classical Science}

In their discourse on the social nature of scientific knowledge, spiritualists do not abandon the juxtaposition of "scientific" and "religious" knowledge that is characteristic of the modern age. This becomes clear in the linguistic clichés that are constantly used in scientific and quasi-scientific polemics about mediumistic phenomena. Their opponents called spiritualists "believers" (people who did not know scientific methods), while in response spiritualists defined their opponents as "dogmatics" (people who had not liberated themselves from "idols"). Thus, "religion," understood first and foremost as a systematic doctrine based on faith, remained for the majority of spiritualists just a set of personal beliefs held by misguided people, and the characteristics associated with it (belief, dogma) were used to underscore the weakness of their opponents' conclusions.

Spiritualists by and large retained the classical conception that the subject of research under ideal conditions allowed for the essence of the studied object to be revealed. However, achieving this set of ideal conditions is not so much associated with a necessary distancing from the object, as with the opposite, having a certain intimate inclination toward that object. So-called "dogmatics" and "skeptics" pushed spiritualists in this direction: the first group refused in principle to initiate study of the object on the basis that it was impossible to violate the laws of physics; while the second group remained unconvinced of the reality of what had occurred even after repeated and direct observation. Skeptics especially shocked spiritualists, who were focused on empiricism and positivism as methodological programs, and forced 
them to admit that direct observation of a phenomenon in scientific research still does not guarantee researchers' agreement in acknowledging the reality of that phenomenon.

Spiritualists closely approached the idea that shared research is based on mutual trust between the researchers. In the end, if trust is not there it is always possible to suggest falsifications and raise questions about the conditions for conducting the experiment. Spiritualists were extraordinarily frustrated by the fact that their scientific authority was insufficient to convince other scholars that their object was not only worthy of study, but in fact actually existed.

Reacting to this cold reception from the scientific community, some of the spiritualists, who held great sympathy for subjective experience, began to adopt two ideas that were completely incompatible with classical epistemology (this is most clearly seen in Nikolai Wagner's works). First off, they demanded researchers believe in the reality of that which they studied. Furthermore, the degree of the intensity and features of the mediumistic phenomena depended on the faith and desire of the appearance of these phenomena in the field of sensory perception. If the researchers did not believe in them, the phenomena may not appear. Secondly, it completely exceeded all possible limits, they argued, that "spirits" with whom the researchers interacted could directly interfere in their experiments, appearing as guides in spiritualist séances.

Within the classical methodology, "knowledge" is viewed as something that the subject should elicit from the world, similar to an investigator, while in spiritualist epistemology it appears as a consequence of the openness of the subject to possible communication with the world of spirits. This epistemological formulation correlates, as it seems, with the well-known understanding of the humanities as knowledge resulting from the interaction between the subject and the object, since in the end it is people who serve as the object in the humanities (and thus knowledge in the humanities becomes self-knowledge). Finally, it is precisely the message of these people that is of critical importance from a humanities' perspective.

Many spiritualists, especially those who regarded contemporary science skeptically, commonly doubted one of the basic aims of the classic methodology of scientific knowledge - to find the hidden causes that governed the object's behavior. Spiritualists' "knowledge" appeared not as a result of analyzing an object within the limits of hypotheses, but rather as the result of "translation" and "decipherment." The researcher, in this case, could be likened to no more than a trans- 
lator. If he even used scientific knowledge, his aim was just to open a channel of communication and to hear the voices of people eternally alive.

Incomplete reproducibility was yet another feature of the research results that spiritualists' opponents often emphasized. Although spiritualists tried to reveal the progressive character in mediumistic manifestations, each time a new manifestation seemed somewhat different than the previous ones. Spiritualists responded to this objection by stating that the conditions of the appearance of these phenomena are still not identified; correspondingly, it is impossible to precisely predict when and how they appear. Moreover, they further argued something more serious, that the properties of their instrument - a medium - have an impact on their object of research, and that therefore the results are new every time. Still, they continued to relate to it as to a "machine," which, with the proper set-up, might achieve the sought-after "ideal" results.

In this way, from the point of view of classical epistemology, the spiritualists' "knowledge," clearly, should have been considered "subjective." On the one hand, the appearance of an object of research depended on the will of the researcher. On the other hand, the object of research became a full-fledged participant of the study, a second subject. "Knowledge" arose not as a consequence of the subject's distancing from the object, but as a result of a joint effort of the subject and the "object." Furthermore, the more a spiritualist trusted his or her subjective experience, the more such "knowledge" acquired social significance and urgency, and resolved crises and even the needs of the spiritualist himself.

Thus among the variety of messages and their interpretation, the figure of Alexander Butlerov always played the role of arbitrator, giving advice on the proper organization of social and political relationships between living people. The contents of his letters from the other side held significance, according to spiritualists, for three reasons. First, they came from a living person with high scientific standing. Second, they came either indirectly in the course of his materialization or through automatic writing. And third, they are not revelations, but simply a continuation of normal social communication. In this respect, from the spiritualists' perspective, the "knowledge" that Alexander Butlerov received in the spiritual world was actually human knowledge.

Of course, "experiments with spirits" could not directly facilitate the emergence of new theories in physics, and in that regard it would 
be overreaching to deem such experiments as precedents for non-classical science. Still, certain aspects of the epistemology of experimental spiritualism, it seems, testify to the movement of several of its representatives in the direction of a non-classical understanding of the features of scientific cognition. In this connection, a standard appeal of spiritualists to various non-classical theories that questioned the classical understanding of "space" (e.g., the mathematical ideas of Bernhard Riemann), also receives its own historical explanation..$^{22}$ This appeal should be seen not only as an attempt to gain a theoretical foundation (for example, using already approved theoretical knowledge as the scientific basis of their own research), nor as an attempt to gain social legitimacy (if spiritualists come to the same conclusions as "scientists," then they are "scientists"), but rather as a testament to methodological proximity between the approaches of non-classical science and this fringe scientific program. ${ }^{23}$

Despite the pointed similarity between non-classical and spiritualist understandings of subject-object relations, the classical model was dominant in spiritualist epistemology, and spiritualists primarily believed in the reality of an existing world and the possibility of knowing it through the aid of special scientific methods. Furthermore, some spiritualists introduced certain elements to scientific cognition, which were in fact not intrinsic to it. First and foremost, their very discovery of a new realm for research was seen as an event capable of leading to the resolution of fundamental questions of ontology (matter and spirit) and anthropology (the spirit and the body). However, a resolution to these questions was never found, for the vast majority of scholars the program did not seem sufficiently convincing, while the problem

22. "Now it seems that the empirical notions on which the metrical determinations of space are founded, the notion of a solid body and of a ray of light, cease to be valid for the infinitely small. We are therefore quite at liberty to suppose that the metric relations of space in the infinitely small do not conform to the hypotheses of geometry; and we ought in fact to suppose it, if we can thereby obtain a simpler explanation of phenomena." Bernhard Riemann, On the Hypotheses Which Lie at the Bases of Geometry, ed. Jürgen Jost (Leipzig: Birkhäuser, 2016), 40 (first written in 1854 and published posthumously in 1868 as Über die Hypothesen, welche der Geometrie zugrunde liegen). [The author originally cites from a Russian-language Soviet collection of Riemann's works (Riemann 1948, 291) - KH].

23. In this regard, one can recall the words of Einstein, who in a conversation with Heisenberg said, "Whether you can observe a thing or not depends on the theory which you use. It is the theory which decides what can be observed." Masud Chaichian, Hugo Perez Rojas, and Anca Turean, eds., Basic Concepts in Physics: From the Cosmos to Quarks (Heidelberg: Springer, 2014), 202. [Author originally cites from a Russian-language Soviet edition, Heizenberg 1970, 303. - KH] 
of the relationship between "science" and "religion" has not lost its relevance even today. Along with this, spiritualists' attempt to overcome the gap between the other reality discovered through "religion," and the reality recognized by "science" was sufficiently original that this unrecognized scientific program left a colorful trace in the intellectual history of the nineteenth century.

\section{References}

Archival Sources

Institut russkoi literatury (hereafter IRLI) [Institute of Russian Literature], f. 2, op. 2, d. 45, l. 1-1ob. Aksakov, A. N. "Spravka, poslannaia mnoiu Vagneru po povodu vsego, chto on v svoei stat'e ob Al. M. Butlerove, 1888 noiabria." [A note, sent by me to Wagner concerning that which is in his article about Al. M. Butlerov, November 1888].

IRLI, f. 2, op. 5, d. 8, 1. 3. "'Soobshchenie' dukha pokoinogo akademika A. M. Butlerova" ['Message' of the spirit of deceased academician A. M. Butlerov].

IRLI, f. 2, op. 5, d. 11, l. 19-19ob. "Zagrobnoe soobshcheniia 'dukha akademika A. M. Butlerova' na seansakh Vagnera i Pribytkovoi," 1892 [A message from the afterlife from the 'spirit of academician A.M. Butlerov' at the séance of Wagner and Pribytkova, 1892].

IRLI, f. 2, op. 6, d. 1. "Gody moei zhizhni v obshchenii s dukhovym mirom. Spiriticheskii dnevnik Marii Petrovny Saburovoi v 3-kh chastiakh, nakhodiashchiisia u menia na khranenii do ee vostrebovaniia. V sluchae moei smerti on dolzhen s eia soglasiia postupit' v Imperatorskuiu publichnuiu biblioteku vmeste s moimi spiriticheskimi knigami. Oktiabr' 1899," [The years of my life in communication with the spiritual world. Spiritualistic diary of Maria Petrovna Saburova in 3 parts, stored at my residence until she requests it. In the case of my death, it should be added with her permission to the Imperial public library along with my spiritualistic books. October 1899].

IRLI, f. 2, op. 17, d. 20, l. 1ob. Pis'mo Vagnera N. P. - Butlerovu A. M. ot 3 marta 1886 [Letter from N.P. Wagner to A. M. Butlerov from March 3, 1886].

IRLI, f. 2, op. 17, d. 21, l. 1-10b. Pis'mo Vagnera N. P. - Butlerovu M. A. ot 10 avgusta 1898 [Letter from N. P. Wagner to M.A. Butlerov dated August 10, 1898].

IRLI, f. 2, op. 17, d. 21, 1. 1ob. Chernoviki pis'ma Butlerova M. A. - Vagneru N.P. ot 22 sentiabria 1898 [M. A. Butlerov letter drafts to N. P. Wagner from September 22, 1898].

IRLI, f. 2, op. 17, d. 21, ll. 2-2ob. Chernovik pis'ma Butlerovoi N. M. - Vagneru N. P. ot 12 noiabria 1893 [Draft of a letter from N. M. Butlerova to N. P. Wagner dated November 12, 1893].

IRLI, f. 2, op. 17, d. 48, ll. 1ob.-2ob. Pis'mo (1) Strel'bitskogo, Al. 1881 [Letter (1) of Al. Strel'bitskii, 1881].

\section{Secondary Sources}

Barbour, Ian G. 2001. “Fizika i Metafizika v XVII veke.” In Religiia i nauka: Istoriia i sovremennost' [Physics and metaphysics in the 17th century. In Religion and science: Historical and contemporary issues], 3-37. 2nd edition. Moscow: Bibleisko-bogoslovskii institut. 
Brooke, John. 2004. "Sud'ba i zadachi estestvennogo bogosloviia." In Nauka i religiia: Istoricheskaia perspectiva [The fate and challenges of natural theology. In Science and Religion: A historical perspective], edited by J. Brook, 166-93. Moscow: Bibleiskii-bogoslovskii institut.

Butlerov, Alexander Mikhailovich. 1889. Stat'i po mediumizmu [Articles on mediumism]. St. Petersburg: A. N. Aksakov.

Comte, Auguste. 1858. The Catechism of Positive Religion. Translated from the French by Richard Congreve. London: Savill and Edwards Printers.

Cunningham, Andrew, and Perry Williams. 1993. "De-Centring the 'Big Picture': 'The Origins of Modern Science' and the Modern Origins of Science." The British Journal for the History of Science 26 (4): 407-32.

de Morgan, Augustus. 1863. From Matter to Spirit: The Result of Ten Years' Experience in Spirit Manifestations. London: Spottiswoods and Co.

Einstein, Albert. 1967. Sobranie nauchnykh trudov [Collection of scientific works]. Vol. 4. Moscow: Nauka.

Falikov, Boris Zinov'evich. 2007. "Palomniki v stranu vostoka.” In Kul'ty i kul'tura [Pilgrims in a country in the East. In Cults and culture], edited by B.Z. Falikov, 18-51. Moscow: RGGU.

Feierabend, Paul. 2007. Protiv metoda. Ocherk anarkhistskoi teorii poznaniia [Against method: Outline of an anarchist theory of knowledge]. Moscow: AST.

Gaidenko, Piama Pavlovna. 2006. "Khristianstvo i genezis novoevropeiskogo estestvoznaniia." In Nauka i religiia: mezhdistsiplinarnyi i kross-kul'turnyi podkhod [Christianity and the genesis of new European natural science. In Science and religion: A multi-disciplinary and cross-cultural approach], edited by Il'ia Kasavin, 79-119. Moscow: Kanon+ Reabilitatsiia.

Grant, Edward. 1996. "The Reception and the Impact of Aristotelian Learning and the Reaction of the Church and Its Theologians." In The Foundations of Modern Science in the Middle Ages, edited by Edward Grant, 70-85. Cambridge: University of Cambridge.

Gregory, Frederick. 2003. "Science and Religion." In From Natural Philosophy to the Sciences: Writing the History of Nineteenth-Century Science, edited by David Cahan, 329-58. Chicago: University of Chicago.

Golinski, Jan. 2005. Making Natural Knowledge: Constructivism and the History of Science. Chicago: University of Chicago.

Heisenberg, Werner. 1970. "Teoriia, kritika i filisophiia.” Uspekhi fizicheskikh nauk [Theory, criticism, and philosophy. Advances in the physical sciences] 102 (2): 298-312.

Lektorskii, Vladislav Alexandrovich. 2009. "O klassicheskoi i neklassicheskoi epistemologii." In Na puti $k$ neklassicheskoi epistemologii [On classical and non-classical epistemology. In On the path to non-classical epistemology], edited by V.A. Lektorskii, 7-24. Moscow: IFRAN.

Malinowski, Bronislaw. 1998. "Magiia, nauka i religiia." In Magiia, nauka i religiia [Magic, science and religion. In Magic, science and religion], edited by B. Malinowski, 19-91. Moscow: Refl-buk.

Markova, Liudmila Artem'evna. 1997. "Nauka i religiia glazami khristianskogo bogoslova S. Iaki.” In Filosofsko-religioznye istoki nauki [Science and religion through the eyes of the Christian theologian S. Yaki. In The philosophical-religious origins of science], edited by P. P. Gaidenko et al., 219-64. Moscow: Martis.

Merton, Robert. 200o. Science, Technology, and Society in Seventeenth-Century England. New York: Howard Fertig. 
Mikeshina, Liudmila Alexandrovna. 2005. Filosophiia nauki: sovremennaia epistemologiia [The philosophy of science: Modern epistemology]. Moscow: Progress-traditsiia.

Mirskaia, Elena Zinovievna. 2005. "R. K. Merton i etos klassicheskoi nauki.” In Filosofiia nauki: Etos nauki na rubezhe vekov [R. K. Merton and the ethos of classical science. In The philosophy of science: The ethos of science at the turn of the century], edited by Larisa Pavlovna Kiiashchenko, 11-28. Moscow.

Osler, Margaret J. 2013. "Religiia i meniaiushchaiasia istoriografiia nauchnoi revoliutsii." Gosudarstvo, religiia, tserkov'v Rossii i za rubezhom [Religion and the changing historiography of the Scientific Revolution. In State, religion, and church in Russia and worldwide] 1 (31): 31-52.

Otto, Rudolf. 2007. Sviashchennoe: Ob irratsional'nom v idee bozhestvennogo i ego sootnoshenii s rational'nym [The idea of the holy: An inquiry into the non-rational factor in the idea of the divine and its relation to the rational]. St. Petersburg: Izd-vo Sankt-Peterburgskogo un-ta.

Popper, Karl. 2003. "Normal'naia nauka i opasnosti sviazannye s nei.” In Struktura nauchnykh revoliutsii [Normal science and the dangers related to it." In The structure of scientific revolutions], edited by Thomas Kuhn, 313-26. Moscow: AST Ermak.

Pribytkov, Viktor Ivanovich. 1901. Spiritizm v Rossii, ot vozniknoveniia do nastoiashchikh dnei [Spiritualism in Russia, from origins to the present day]. St. Petersburg: Red. zhur. "Rebus."

Razdyakonov, Vladislav S. 2010. “Rassvet i zakat 'eksperimental'nogo spiritisma' v Rossii 1880-1890-kh godov" [The dusk and dawn of "experimental spiritualism" in Russia in the 1880s-1890s]. Vestnik RGGU 15: 162-71

- - . 2013. "Khristianskii spiritizm N.P. Vagnera i ratsional'naia religiia A. N. Aksakova mezhdu 'naukoi' i 'religiei. "” [The Christian spiritualism of N.P. Wagner and the rational religion of A. N. Aksakov between "science" and "religion."] Vestnik PSTGU I. Bogoslovie. Filosofiia 48 (4): 55-72.

-—-. 2015. "Dukhovnye avtoritety sekuliarnogo veka: spiriticheskii dnevnik M. P. Saburovoi." [Spiritual authorities of the secular age: The spiritualist diary of M. P. Saburova.] Vestnik PSTGU I. Bogoslovie. Filosofiia. 62 (6): 55-69.

Riemann, Bernhard. 1948. Sochineniia [Essays]. Moscow-Leningrad: Gostekhizdat.

Saprykin, Dmitrii Leonidovich. 200o. “Nauchnyi orden’ Fransisa Bekona: zarozhdenie nauchnogo obshchestva novogo tipa” ['The Scientific Order' of Francis Bacon: The genesis of a new kind of scientific society]. Naukovedenie 3: 194-208.

Stepin, Viacheslav Semenovich. 2009. "Klassika, neklassika, postneklassika: kriterii razlicheniia.” In Postneklassika: filosofiia, nauka, kul'tura [Classical, non-classical, postclassical: Discerning criteria. In Postclassical: Philosophy, science, culture], edited by L. P. Kiiashchenko, 249-95. St. Petersburg: Pechatnyi dvor im. A. M. Gor'kogo.

Svetlov, Viktor Alexandrovich. 2008. "Metod idealizatsii Galileo Galileia: matematika kak iazyk prirody." In Istoriia nauchnogo metoda ["The method of idealizing Galileo Galilei: Mathematics as the language of nature." In The history of the scientific method], edited by V.A. Svetlov, 96-110. Moscow: Akademicheskii proekt.

Whitehead, Alfred North. 2009. Prikliucheniia idei [Adventures of ideas]. Translated into Russian by L. B. Tumanova. Moscow: In-t filosofii RAN.

Wright, T. R. 2008. The Religion of Humanity: The Impact of Comtean Positivism on Victorian Britain. Cambridge: University of Cambridge.

Zhmud', Leonid Yakovlevich. 2012. Pifagor i rannie pifagoreitsy [Pythagoras and early pythagoreans]. Moscow: Un-t D. Pozharskogo. 